\title{
KSHV activation, human and viral IL-6 production, and other cytokine dysregulation: Association with the symptomatology of KSHV-associated multicentric Castleman's disease
}

\author{
Mark N Polizzotto ${ }^{1 *}$, Thomas S Uldrick ${ }^{1}$, Victoria Wang ${ }^{1}$, Karen Aleman ${ }^{1}$, Kathleen M Wyvill' ${ }^{1}$ Vickie Marshall ${ }^{3}$, \\ Stefania Pittaluga ${ }^{2}$, Dierdre O'Mahony ${ }^{1}$, Denise Whitby ${ }^{3}$, Giovanna Tosato ${ }^{4}$, Seth M Steinberg ${ }^{5}$, Richard F Little ${ }^{1}$, \\ Robert Yarchoan ${ }^{1}$
}

From $12^{\text {th }}$ International Conference on Malignancies in AIDS and Other Acquired Immunodeficiencies (ICMAOI)

Bethesda, MD, USA. 26-27 April, 2010

\section{Background}

KSHV-associated multicentric Castleman's disease $(\mathrm{MCD})$ is a frequently fatal lymphoproliferative disorder characterized by inflammatory flares of fever, cytopenias, hypoalbuminemia, hyponatremia, and splenomegaly. Most cases occur in HIV-infected patients. KHSV viral interleukin-6 (vIL-6), human IL-6 (hIL-6), and possibly other proinflammatory cellular cytokines are believed to contribute to the pathophysiology of MCD flares.

\section{Methods}

We identified MCD patients with clinical flares. KSHV viral load (VL) in peripheral blood mononuclear cells, vIL-6, and the cellular cytokines IL-6, IL-1b, IL-8, IL-10, IL-12p70, interferon gamma, and tumor necrosis factor alpha were measured during flares and remissions to identify parameters best characterizing flares. The assay for vIL- 6 was modified from Aoki Y. et al., Blood, 97, 2526, 2001; the cutoff of detection was 1560 $\mathrm{pg} / \mathrm{ml}$. Factors statistically associated with flares $(\mathrm{p}<0.01)$ were explored in relationship to common disease manifestations with multiple linear regression models.

\footnotetext{
*Correspondence: polizzottomn@mail.nih.gov

${ }^{1} \mathrm{HIV}$ and AIDS Malignancy Branch, Center for Cancer Research, National

Cancer Institute, Bethesda, MD, USA

Full list of author information is available at the end of the article
}

\section{Results}

20 patients (18 male, 2 female) were studied during 33 flares (range 1-3 per patient) and, in 18 patients, remission with therapy. Median (range) values of key parameters during flares included hemoglobin $9.9 \mathrm{mg} / \mathrm{dL}$ (6.8-14.4); platelet count $97 \mathrm{~K} / \mu \mathrm{L}$ (6-377); sodium $133 \mathrm{mEq} / \mathrm{L}$ (127143); albumin $2.7 \mathrm{mg} / \mathrm{dL}$ (1.2-3.9); spleen size $14.5 \mathrm{~cm}$ (928); temperature $38^{\circ} \mathrm{C}(36.1-40.5)$; CD4 count 240 cells/ $\mu \mathrm{L}$ (24-1319); HIV VL $<50$ copies/mL (<50-64100). Flares were associated with elevated KSHV VL (median 23448 copies/mL; range 0-3913043; $\mathrm{p}<0.0001$ compared with remission), vIL-6 (2575 pg/mL; <1560-20497; $\mathrm{p}=0.0039)$, hIL-6 (24.2 pg/mL; 1.4-171.5; p=0.0034), hIL-10 (783.9 pg/ $\mathrm{mL} ; 2.8-26021 ; \mathrm{p}=0.0027)$, and hIL-1b $(1.3 \mathrm{pg} / \mathrm{mL} ; 0-11.3$; $\mathrm{p}=0.0074$ ). In two of the 33 flares vIL- 6 was elevated but hIL-6 was not; in 14 hIL- 6 was elevated but vIL6 was undetectable; and in 15 both were elevated. Neither was initially elevated in 2 flares, but hIL-6 later became elevated in both. Disease manifestations did not differ among flares with differing vIL-6/hIL-6 profiles. In multiple regression analysis, elevated KSHV VL was the strongest predictor of level of hemoglobin $(\mathrm{p}<0.0001)$, sodium $(\mathrm{p}<0.0001)$, albumin $(\mathrm{p}<0.0001)$, and spleen size $(\mathrm{p}=0.0002)$; hIL-6 the strongest predictor of thrombocytes $(\mathrm{p}=0.0011)$, and KSHV and hIL-6 together the strongest predictors of body temperature $(\mathrm{p}<0.0001)$. For hemoglobin, but not other parameters, vIL- 6 and hIL- 6 in combination were stronger predictors than either independently $(\mathrm{p}=0.0002)$, though less strong than KSHV VL alone. 


\section{Conclusions}

KSHV activity, vIL-6 production, and associated human hIL-6 dysregulation are key determinants of the clinical manifestations of MCD. vIL-6 and hIL-6 each appear sufficient to induce flares without the other. hIL-10 and hIL- $1 ß$ are also elevated in MCD flares, but their contribution to symptomatology remains to be determined.

\section{Acknowledgements}

This article has been published as part of Infectious Agents and Cancer Volume 5 Supplement 1, 2010: Proceedings of the $12^{\text {th }}$ International Conference on Malignancies in AIDS and Other Acquired Immunodeficiencies (ICMAOI). The full contents of the supplement are available online at http://www.biomedcentral.com/1750-9378/5?issue=S1.

\section{Author details}

${ }^{1} \mathrm{HIV}$ and AIDS Malignancy Branch, Center for Cancer Research, National Cancer Institute, Bethesda, MD, USA. ${ }^{2}$ Laboratory of Pathology, Center for Cancer Research, National Cancer Institute, Bethesda, MD, USA. ${ }^{3}$ Viral Oncology Section, AIDS and Cancer Virus Program, National Cancer Institute, Bethesda, MD, USA. ${ }^{4}$ Laboratory of Cellular Oncology, Center for Cancer Research, National Cancer Institute, Bethesda, MD, USA. ${ }^{5}$ Biostatistic and Data Management Section, Center for Cancer Research, National Cancer Institute, Bethesda MD, USA.

Published: 11 October 2010

\section{Submit your next manuscript to BioMed Central} and take full advantage of:

- Convenient online submission

- Thorough peer review

- No space constraints or color figure charges

- Immediate publication on acceptance

- Inclusion in PubMed, CAS, Scopus and Google Scholar

- Research which is freely available for redistribution

Submit your manuscript at www.biomedcentral.com/submit 